 \\ Journal of Transportation and Logistics \\ 3 (2), 2018
}

Research Article

\section{Clustering Analysis of Turkish Maritime Transportation Sector}

\author{
Cengiz Bahadır Karahan | Istanbul Technical University, Turkey, cbkarahan@itu.edu.tr
}

Levent Kırval | Faculty of Maritime, Department of Basic Sciences, Istanbul Technical University, Turkey, Ikirval@itu.edu.tr

\section{ABSTRACT}

\section{Keywords:}

Clusters,

Maritime Clusters

Maritime

Transportation

Sector,

Location Quotient,
Turkey is a maritime country with its current fleet, geographical location, young population and growth potential. This study aims to measure and map the main characteristics of Turkish maritime transportation sector by using the cluster approach. Clustering, being one of the important improvement methods of global competition power, is widely used in the maritime transportation sector. Analysing the maritime clustering potential in a quantative way is a basic step to increase the global competitiveness in this sector. In this context, the level of Turkish maritime transportation cluster is measured by means of Location Quotient (LQ) in this article. It concludes that among the 6 statistically grouped counties, TR 10 Istanbul county is showing significant potential according to all variables.

Competitiveness

\section{Türk Deniz Taşımacılığı Sektörünün Kümelenme Analizi}

öz

\section{Anahtar Sözcükler :}

Kümelenmeler

Denizcilik

Kümelenmeleri,

Deniz Taşımacılığı

Sektörü,

Coğrafi Yoğunluk Katsayısı,

Küresel Rekabet

Gücü
Türkiye sahip olduğu mevcut filosu, coğrafi konumu, genç nüfusu ve büyüme potansiyeli ile önemli bir denizcilik ülkesidir. Bu çalışma kümelenme yaklaşımını kullanarak Türk deniz taşımacılığı sektörünün ana özelliklerini ölçmeyi ve haritalandırmayı amaçlamaktadır. Küresel rekabet gücünün geliştirilmesinde önemli bir kavram olan kümelenme deniz taşımacılığı sektöründe de yaygın olarak kullanılmaktadır. Türk deniz taşımacılığı sektörünün özellikle sayısal yöntemler kullanılarak kümelenme analizinin yapılması küresel rekabet gücüne kavuşulmasında önemli bir basamaktır. Bu kapsamda Türk deniz taşımacılığı sektörünün kümelenme seviyesi Coğrafi Yoğunluk Katsayısı (Location Quotient (LQ)) kullanılarak ölçülmüştür. Toplam 6 istatistiki bölge dikkate alınarak yapılan incelemede TR 10 İstanbul bölgesinin tüm değişkenler açısından güçlü kümelenme özellikleri gösterdiği tespit edilmiştir.

\section{Cite this article as}

Karahan, C. B. \& Kırval, L. (2018). Türk Deniz Taşımacılığı Sektörünün Kümelenme Analizi. Journal of Transportation and

Logistics, 3(2), 63-80. doi: 10.26650/JTL.2018.03.02.02 


\section{Extended Abstract}

\section{Clustering Analysis of Turkish Maritime Transportation Sector}

Research Problem: Clustering, being one of the important improvement methods of global competition power, is widely used in the maritime transportation sector. It is vital for Turkey to be a global actor in this sector. To achive this goal cluster concept could be established and developed in national and regional dimensions having both subsectoral and integrated aspects. This study aims to measure and map the main characteristics of Turkish maritime transportation sector by using the cluster approach.

Research Question: The research question is which statistical regions of Turkey have clustering potential in maritime transportation sector in terms of Location Quotient (LQ).

Methodology: Analysing the maritime clustering potential in a quantative way is a basic step to increase the global competitiveness in this sector. In this context, the clustering level of Turkish maritime transportation sector is measured by means of Location Quotient (LO) in this article. LO method is used to analyse and compare the sectoral agglomeration and clustering of different geographic locations such as regions and cities. Maritime transportation sector is classified with NACE 50 code according to Statistical Classification of Economic Activities in the European Community (NACE). Turkish maritime transportation sector has been analysed by using "Some Basic Indicators by Local Units" data which has been published by Turkish Statistical Institute (Turkstat). The data between 2009-2015 (the means of 7 year-period are used) contains number of local units, number of persons employed, wages-salaries, turnovers and gross investment in tangible goods. The regions which have been analysed according to the Nomenclature of Territorial Units for Statistics (NUTS) were screened in terms of their LO levels and whether they had a coastline or not.

Results and Conclusions: This study concludes that among the 6 statistically grouped counties, TR 10 Istanbul county is showing significant potential according to all variables. It has a well-developed maritime transportation cluster in terms of various parameters such as number of persons employed, number of local units, turnovers, wages-salaries and gross investment in tangible goods. This county is evaluated as a good candidate for competing with its rivals throughout the globe. Also TR 32 Aydin-Denizli-Mugla, TR 22 Balikesir-Canakkale and TR 31 Izmir statistical counties are well-developed clusters in terms of number of persons employed and number of local units. TR 61 Antalya-Burdur and TR 62 Adana-Mersin statistical counties have potential to become maritime transportation clusters in the future although they are below the threshold at present. In this study in order to support and/or interrogate LO values based on employment; turnovers, wages-salaries and gross investments in tangible goods data has been used in an experimental manner. In this scope, it has been found that some LO values based on employment and establishments would give deceptive results and hide the weaknesses of the clusters because of the high number of small and medium size entreprises in the region. In such cases the variables such as turnovers, wages-salaries and gross investments in tangible goods which highly represent economic condition and added value creation would work better than number of persons employed and number of local units variables.. 


\section{Giriş}

Belirli bir sektör ve alt/ilişkili sektörlerdeki firmaların ve ilgili kurum ve kuruluşların yüksek seviyeli işbirliği içinde coğrafi anlamda yoğunlaşmaları, diğer bir ifadeyle kümelenmeleri, rekabetçiliklerini olumlu yönde arttırabilmektedir. Bu şekilde hem kendi aralarında rekabet eden hem de belirli alanlarda işbirliğine giden firmaların küresel anlamda rekabet gücü elde etmeleri mümkün hale gelmektedir (Porter 1990).

Bu çalışmamızda Türk deniz taşımacılığı sektörünü kümelenme bakış açısıyla inceleyeceğiz. Giriş bölümünde kümelenmenin tarihsel gelişimine ve faydalarına yer verilecek, ikinci bölümde kümelenme literatürü coğrafi boyutları açısından özetlenecek, üçüncü bölümde Türk deniz taşımacılığı sektörünün genel durumu ortaya konacaktır. Dördüncü bölümde kümelenmenin sayısal analizine yönelik olarak kullanılan LO yöntemi açıklanacak, beşinci bölümde ise Türk deniz taşımacılığı sektörünün kümelenme seviyesinin belirlenmesi amacıyla elde edilen bulgulara yer verilecektir. Altıncı ve son bölüm olan sonuç bölümüyle çalışma tamamlanacaktır.

Kümelenmeyi 1990'lardan itibaren önemli kavram haline getiren Porter'a göre bir kümelenme; birbirleriyle rekabet eden ama aynı zamanda işbirliği de yapan belirli alanlarda birbirlerine bağlı şirketler, uzman tedarikçiler, hizmet sağlayıcılar, ilgili sektördeki firmalar ve bağlantılı kurumlardan oluşan coğrafi yoğunlaşmadır. Kümelenme modeli kısaca, aynı sektörde faaliyet gösteren işletmelerin yerel, ulusal, bölgesel ve küresel rekabet gücü elde etmek amacıyla, bağımsızlıklarını koruyarak bir araya gelmeleri ve rekabet içinde işbirliği yapmaları olarak tanımlanmaktadır. (Porter 1990, 2000).

Medeniyetin ilk oluşum zamanlarından itibaren birtakım malların ve hizmetlerin üretiminde özellikle ilgili hammaddelerin var olmasına, ticaret yollarına ve şehirlerin gelişimine bağlı olarak yoğunlaşma, yerelleşme ve kümelenmenin örnekleri görülmektedir.

Bu konuda ilk çalışmalar, 1826 yılında yayınladığı 'Izole Edilmiş Devlet' isimli çalışmasında tarımsal üretimin ve arazi kullanımının nasıl şehirler etrafında yoğunlaşma eğiliminde olduğunu açıklayan von Thunen'e kadar uzanmaktadır (Aziz ve Norhashim 2008).

Kümelenmenin temelleri, son derece iyi tesis edilmiş ve zamanında ekonomiye yön veren çeşitli mesleki örgütlenmelerle yüzyıllar öncesine kadar uzansa da düşünsel olarak Alfred Marshall'ın 1890 yılında basılan Principles of Economics (Ekonominin ilkeleri) kitabında özel sanayi bölgelerine yer vermesiyle literatür oluşmaya başlamıştır. Neo-klasik iktisadın öncüsü olan Marshall, coğrafyanın ekonomiye olan etkisini inceleyerek belirli yerlerde yoğunlaşmış endüstrilerin uzmanlaşmış işgücünü arttırdığını, uzmanlaşmış ara malı ve hizmet tedarikçilerini geliştirdiğini ve sektörler arasında teknoloji transferini kolaylaştırdığını belirtmiştir (Van den Berg ve Lewer 2007). Marshall'a göre yerelleşmenin sebepleri; belirli girdilerin varlığı, işgücü havuzu, bilgi ağı, yerel talep, ilişkili endüstriler ve bölgenin sosyo-ekonomik özellikleridir. Ayrıca eğer bir endüstri belli bir bölgede konumlanıp kümelenme oluşturursa, muhtemelen çok uzun bir süre için orada kalacağından avantajları da çok fazla olacaktır (Öz 2004).

Hoover, Marshall'dan sonra onun prensiplerini devam ettirmiş ve açıklama getirmiştir. Aynı veya farklı endüstrilerde kümelenmiş firmaların ve iş alanlarının, tek bir firmanın 
başarısı üzerine; ekonominin yerelleşmesi, şehir ekonomisi ve ölçek ekonomisi açısından önemli katkısı olduğunu belirtmiştir. Weber, Marshall'ın öncü fikirlerini geliştiren bir diğer akademisyendir. Yoğunlaşma ile beraber düşük üretim ve taşımacılık maliyetlerinin önemine vurgu yapan Weber yerelleşme teorisine katkıda bulunmuştur. Weber'e göre, üretimin coğrafi unsurları temel olarak pazar ve girdilerin konumlarına bağlıdır (Öz 2004).

Marshall'dan yüzyıl sonra Porter, birtakım ülkeleri ve endüstrilerini inceleyerek diğer ülkelere göre neden daha rekabetçi oldukları konusunda araştırmalar yapmış ve kümelenme konusuna popülerlik kazandırmıştır. Ulusların rekabet üstünlüğü, coğrafyanın rekabete etkisi, kümelenme, yenilikçilik, vb. kavramları Elmas Modeli olarak adlandırılan birtakım unsurlara ve söz konusu unsurların birbirleri arasındaki etkileşimine dayandırmıştır. Söz konusu modelde bir sektörün rekabet avantajını etkileyen dört ana faktör belirlemiştir. Bu temel değişkenler elmasın köşelerini oluşturan; faktör koşulları, talep koşulları, firma stratejisi, yapısı ve rekabet ve ilgili ve destekleyici sektörlerdir. Elmas teorisi kısaca bu köşelerin kendi arasındaki ve ayrıca devlet ve şans gibi bu dört faktörü dışarıdan etkileyen dışsal boyutlarla arasındaki ilişkiyi açıklamaktadır (Porter 2000).

Kümelenmenin faydaları şu şekilde özetlenebilir:

- Yenilikçiliği destekleyen ve kümelenmeyi genişleten iş oluşumlarının teşvik edilerek yenilikçilik ve üretkenlik kapasitesinin arttırılması ve bu şekilde kümelenmeyi oluşturan firmaların veya sektörlerin üretkenliğinin ve istihdamın artırıması,

- Uzmanlaşmış girdilere üstün veya daha düşük maliyetli erişimin sağlanması, girdilerin küme elemanlarından temini ile daha uzaktan teminine kıyasla daha düşük işlem maliyeti avantajı yaratılması.

- Firmalar arasında koordinasyonun arttırılması, rekabetçi bir işbirliğinin kurulması, bilgiye erişimin hızlanması, ortak bilimsel araştırmaların kolaylaşması, sektörel gelişmelerin daha iyi takip edilmesinin sağlanması, iyi örneklerin yayılmasını hızlandırarak ve rakipler arasında performans kıyaslaması yapılmasına (benchmarking) imkan tanıyarak verimliliğin ve etkinliğin arttırıması,

- Tedarikçilere, müşterilere ve destekleyici kurumlara daha rahat ulaşılmasıyla bilgili ve tecrübeli alıcıların talepleriyle rekabetçi ve yetkin tedarikçilerin gücünün birleştirilmesi, bu şekilde yeni ürünlerin/hizmetlerin ortaya çıkmasının kolaylaştırılması,

- Kamu imkanlarına daha kolay ulaşılması, teşvik ve hibelerden yararlanma imkânının artması, finans kaynaklarının daha iyi kullanılabilmesidir (Porter 2000).

\section{Literatür Taraması}

Coğrafi temelde kümelenmenin genel ve denizcilik boyutunda önemine ilişkin geniş bir literatür bulunmaktadır. Porter'la eşzamanlı olarak coğrafyanın ekonomiye etkisini araştıran Krugman bir ülkenin endüstrileşmiş merkez ve tarımsal çevre şeklinde farklılaşmasını ve söz konusu merkez-çevre arasındaki ilişkiyi incelemiştir. Çalışmasında, taşıma giderlerinin azaltılması ve ölçek ekonomilerinin hayata geçirilmesi kapsamında üretim faktörlerinin talebin yoğun olduğu bölgelerde yoğunlaşırken, talebi oluşturan kesimlerin de üretimin gerçekleştiği coğrafyalara yerleştiğini belirtmiştir (Krugman 1991). 
Saxenian (1996), ABD'de bulunan Route 128 ve Silikon Vadisi teknoloji kümelenmeleri özelinde coğrafi konumların rekabetçiliğe olan etkilerini karşılaştırmıştır. Massachusetts'deki Route 128'de bulunan ileri teknoloji kümelenmesinde var olan katı hiyerarşik yapının ve şirket temelli yenilikçilik algısının söz konusu kümelenmenin zamanla etkisini yitirmesine sebep olduğunu, buna karşın California'daki Silikon Vadisi ileri teknoloji kümelenmesinin daha esnek yönetim anlayışı ve yenilikçilik kültürünü yerel ölçekli ağlarla geliştirmesi sayesinde küresel rekabet gücünü arttırdığını belirtmiştir.

Porter (1998), coğrafi konumun ve kümelenmenin rekabete etkisini incelemiştir. Firmaların düşük girdi maliyetlerinin (ucuz işgücü ve hammadde, düşük vergi oranları, vb.) bulunduğu yerlere yatırım yapmalarının ilk başta maliyet avantajı yaratabileceğini fakat günün sonunda toplam maliyetler göz önünde bulundurulduğunda kümelenmenin içinde bulunmanın çok daha önemli avantajlar (güçlü altyapı ve ilişki ağı, uzman işgücü, yüksek yenilikçilik kapasitesi, vb.) sağladığını belirtmiş̧tir

Porter (2000) kümelenmelerin küresel ekonomi içindeki yerini incelediği çalışmasında, küreselleşme ile coğrafi özelliklerin rekabete olan etkisinin bir paradoks oluşturduğunu fakat kümelenmeleri tarihsel ve geleneksel anlamından farklı olarak giderek önemi artan karmaşık, bilgi temelli ve dinamik ekonomiler bağlamında değerlendirmek gerektiğini vurgulamıştır. Kümelenmenin tanımını yapmış, rekabet üstünlüğüne etkilerini (verimlilik, yenilikçilik, yeni iş oluşumu, vb.) ortaya koymuş, devletin kümelenmedeki rolüne ve kümelenmenin ekonomik kalkınmanın örgütlenmesi ve kamu politikalarının oluşturulmasına ilişkin katkılarına değinmiştir.

Porter'ın 1990'lı yıllarla birlikte popüler hale getirdiği elmas modeli temelli kümelenme yaklaşımı birçok akademisyenin çalışmasına ilham olmuştur. Çoğunlukla gelişmiş ülkelerin endüstriyel ve hizmet sektörlerinin konu alındığı vaka analizleri şeklindeki çalışmalara örnek vermek gerekirse; İsveç kümelenmeleri Lundequist ve Power (2002), Kanada kümelenmeleri Wolfe ve Gertler (2004), Almanya kümelenmeleri Rocha ve Sternberg (2005), Norveç kümelenmeleri Reve ve Sasson (2015) tarafından incelenmiştir.

Rosenfeld (2003) kümelenme içindeki güçlü sosyal sermayenin ve bunun sağladığı bilgi yayılmasının istihdam, ekonomik gelişme ve yenilikçiliğe olan katkısından bahsetmiş, kümelenmenin faydalarının daha geniş çevrelere aktarılabilmesine yönelik stratejileri ortaya koymuştur. Kümelenmelerin, coğrafi yakınlığa dayandığını ve mekansal sınırlara sahip olduğunu, insanların çalışmak için yolculuk yapmayı göze aldıkları ve firma sahiplerinin diğer aktörlerle bir ağ oluşturmak için makul gördükleri mesafe ve zamanın kümelenmenin sınırlarını belirlediğini belirtmiştir.

Enright (2003) kümelenme tipleri arasındaki farklılıkların firmaların ve hükümetlerin ulusal ve bölgesel kümelenme stratejilerini ve politikalarını oluştururlarken önemli rol oynadığını belirtmiştir. Ülkeler arasında kıyaslama yapacak sağlıklı bir istatistiki altyapının eksikliğinin kümelenme çalışmalarını zorlaştırdığını ve akademisyenler arasında kümelenmenin etkili bir politika aracı olup olmadığı konusunda şüpheye yol açtığını vurgulamıştır.

Kümelenme literatüründe kümelenme seviyesinin ölçülmesinin önemini ortaya koyan birçok çalışma bulunmaktadır. Örneğin; Ketels ve Memedovic (2008), kümelenme haritasının çıkartılmasının ve kümelenme gelişiminin sürekli izlenmesinin önemli 
olduğunu belirtmiştir. Benzer şekilde Wijnost (2006), denizcilik sektörünün takibini sağlayacak sağlam bir istatistiki altyapının kurulması gerektiğini ortaya koymuştur. Kümelenme ile girişimcilik ve istihdam seviyeleri arasındaki ilişkiyi inceleyen birçok çalışma bulunmaktadır. Delgado vd. (2010), bölgesel endüstriyel seviyede kümelenme ve yığışım ekonomilerinin girişimciliğin artışına olan etkisini incelemiş, kümelenmenin girişimciliği arttırdığını ortaya koymuştur. Ayrıca Delgado vd. (2014), bölgesel kümelenme kompozisyonunun sektörel performans üzerindeki etkisini incelemiş, güçlü kümelenmelerin bulunduğu bölgelerdeki firmaların patent sayısındaki ve istihdamdaki artış miktarının daha yüksek olduğunu tespit etmiştir.

Denizcilik kümelenmelerine ilişkin literatür incelendiğinde Kuzey Avrupa kaynaklı çalışmaların çoğunlukta olduğu, söz konusu çalışmalardan özellikle Norveç, Hollanda, İngiltere gibi ülkelerin denizcilik kümelenmelerinin incelendiği vaka analizlerinin ön plana çıktığı görülmektedir. Ayrıca Çin, Japonya, G. Kore, Yunanistan, Panama, vb. denizcilikte söz sahibi ülkelere ait çalışmalar da tespit edilmiştir. Denizcilik sektörüyle ilgili yapılan çalışmalarda da kümelenmenin coğrafi özellikleri, istihdama ve girişimciliğe etkisi, sağlam verilerle kümelenme seviyesinin sürekli olarak ölçülmesi konuları ele alınmıştır. De Langen (2002), Hollanda denizcilik kümelenmesini; kümelenme içindeki yığışım ekonomisinin varlığı ve kümelenme performansı açısından değerlendirmiş, firmaları kümelenmeye teşvik eden avantajların; işgücü havuzu, geniş tedarikçi ve müşteri tabanı, bilgi taşması ve düşük işlem maliyetleri olduğunu belirtmiş̧tir. Brett (2007), Greater Dublin Region (GDR) bölgesinin denizcilik sektörünün gerçekten bir denizcilik kümelenmesi olup olmadığını incelediği çalışmasında, önemli denizcilik kümelenmelerinin; çok sayıda firma ve çalışana sahip olma özelliklerinin bulunduğunu ortaya koymuştur. Viederyte (2014a, 2014b), Litvanya denizcilik kümelenmesinin ekonomik büyümesinin Litvanya ekonomisine olan etkisi kümelenme perspektifinden ve çalışan ve firma sayısı, ciro, sermaye yatırım oranı, toplam işlem karı ve katma değerli üretim göstergelerini kullanarak değerlendirmiş̧tir.

Türkiye'nin belirli bir sektörünü ulusal anlamda ele alan ve söz konusu sektörün küresel rekabet gücünün arttırılması anlamında önerilerde bulunan çalışmalar bulunmaktadır. Örneğin; Bulu vd. (2006) Türk elektronik sektörünü, Alüftekin vd. (2009) Türk tekstil kümelenmesini, Karahan (2014) Türk demiryolu taşımacılığını, Gebeş ve Battal (2014) Türk havacılık kümelenmesini, Kocaoğlu (2013) Türkiye doğal taş kümelenmelerini, Mutlucan (2015) Türkiye'deki tekstil, hazır giyim, halı, otomotiv, turizm ve mobilya kümelenmelerini incelemiştir. Türk denizcilik sektörünü konu alan çalışmalar değerlendirildiğinde; Deval ve Saman (2005) İstanbul Denizcilik kümelenmesinin SWOT analizini yapmış, Gürbüz (2008) Türk denizcilik kümelenmesinin $A B$ denizcilik kümelenmelerini örnek alarak nasıl örgütlenebileceğini değerlendirmiş, Sartaş (2010) Türk gemi inşa kümelenmesinin büyüme dinamiklerini ve gelecek beklentilerini araştırmış ve Akıncılar Tan (2011) askeri ve sivil teknolojinin birleşimi amaçlı kümelenmeyi askeri gemi yapımı örneğinde incelemiştir.

\section{Türk Deniz Taşımacılığı Sektörü}

Türk deniz taşımacılığı sektörünün mevcut durumu, üç tarafı denizlerle çevrili ve küresel anlamda nispeten merkezi bir konumda bulunan Türkiye'nin genel potansiyeli dikkate alındığında ne yazık ki arzulanan düzeyde değildir. 01 Ocak 2017 tarihi 
itibariyle ve 1000 GT ve üzeri gemiler dikkate alındığında, Türk sahipli deniz ticaret filosu 1547 adet gemiye, 29.265.000 DWT ve 259.000 TEU kapasiteye sahiptir (DTO 2017). Şekil 1'de Türk deniz taşımacılığı sektörüne ilişkin birtakım istatistiki bilgilerin grafiksel olarak gösterimine yer verilmiştir. Türk sahipli deniz ticaret filosu milli ve yabancı bayraktaki gemiler dikkate alındığında (1000 gt'nun üzeri) dünyada 15 . sırada (Şekil 1a), sadece milli bayraktaki gemiler dikkate alındığında (300 gt'nun üzeri) ise dünyada 23. sıradadır. Türk sahipli toplam gemi sayısının ve tonajının 1999 - 2017 yılları arasındaki değişimi Şekil 1b ve Şekil 1c'de grafiksel olarak gösterilmiştir (DTO 2017). Şekillerde Türk sahipli toplam gemi sayısının ve tonajının, 2008 küresel ekonomik krizinin olumsuz etkilerine rağmen söz konusu süre içinde yaklaşık 3 kat arttığı kolaylıkla fark edilmektedir. Bununla birlikte Türk deniz ticaret filosunda 2017 itibariyle 1000 DWT'un üzerinde 585 adet gemi bulunmaktadır. Bu gemilerin 70 adedi Milli Sicile, 508 adedi ise TUGS (Türk Uluslararası Gemi Sicili)'ne kayıtıdır. Türk deniz ticaret filosunun siciller arası dağıımı Şekil 1d'dir. Türkiye'nin mevcut sıralamalardaki yeri ve nispeten yaşlı filosu dikkate alındığında, küresel ticaretin yaklaşık \% 90'ının ve Türkiye'nin ticaretinin yaklaşık \%86'sının deniz yoluyla yapıldığı bir ortamda deniz taşımacılığı sektörüne daha çok önem vermesi gerekmektedir (DTO 2017).

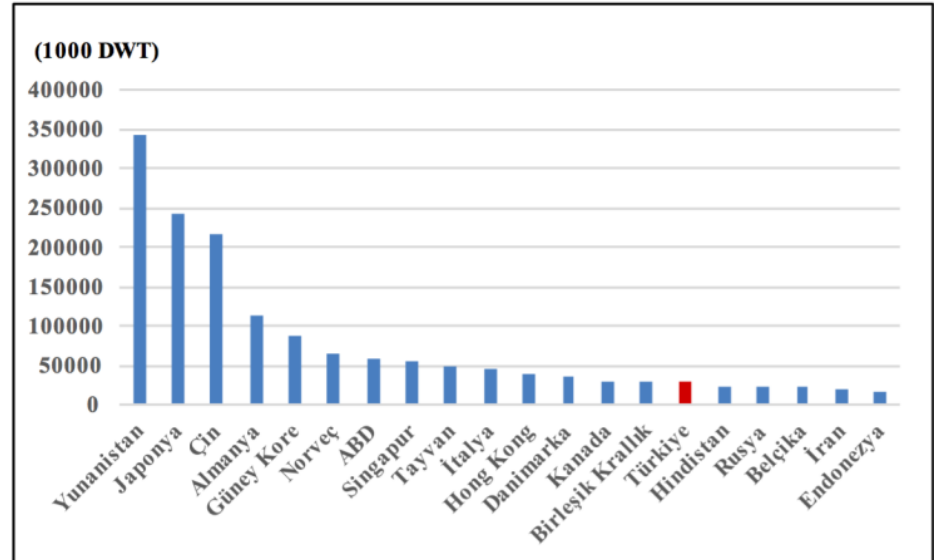

Şekil 1a. Dünyada Deniz Taşımacılığında İlk 20 Ülkenin Sahip Oldukları Tonaj (Kaynak: DTO 2016 Deniz Sektörü Raporu)

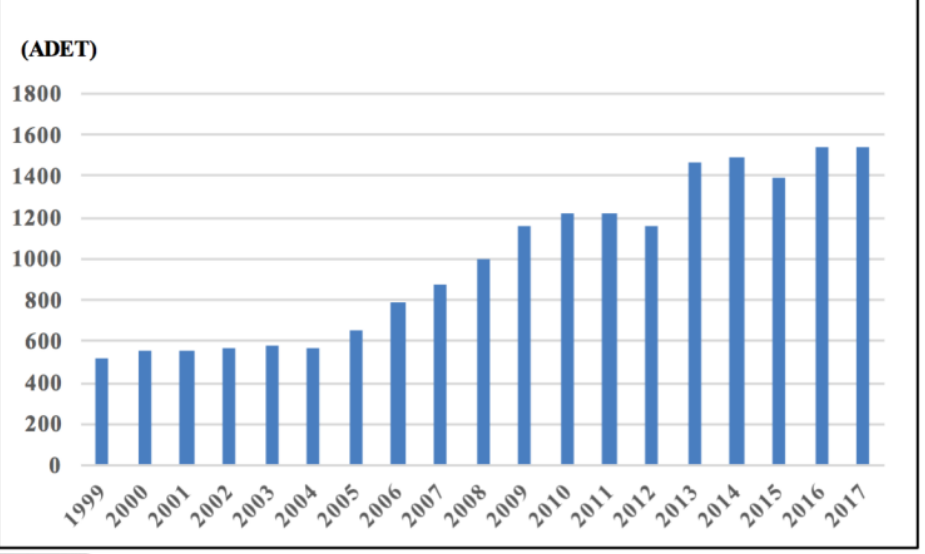

Şekil 1b. Türk Sahipli Toplam Gemi Sayısının Yıllara Göre Değişimi (Kaynak: DTO 2016 Deniz Sektörü Raporu) 


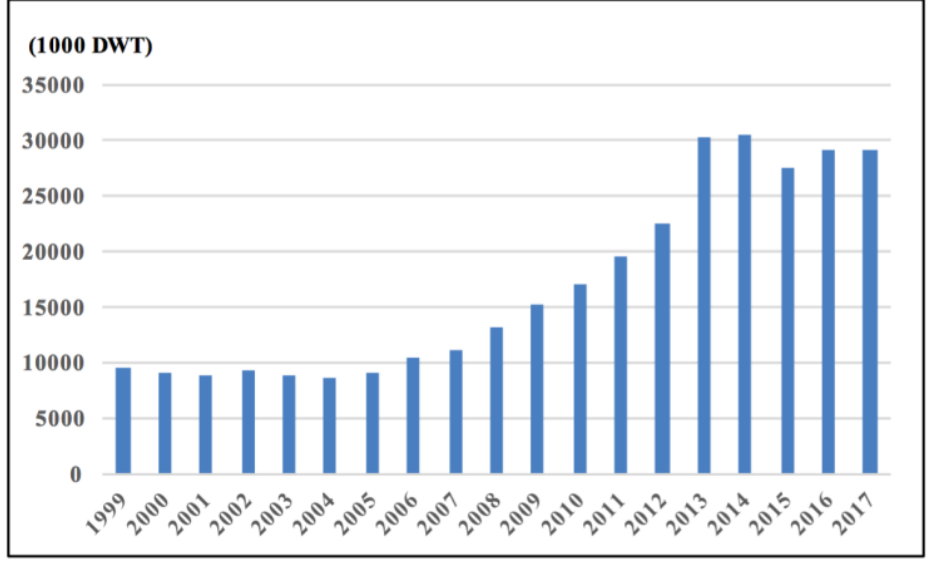

Şekil 1c. Türk Sahipli Toplam Gemi Tonajının Yıllara Göre Değişimi(Kaynak: DTO 2016 Deniz Sektörü Raporu)

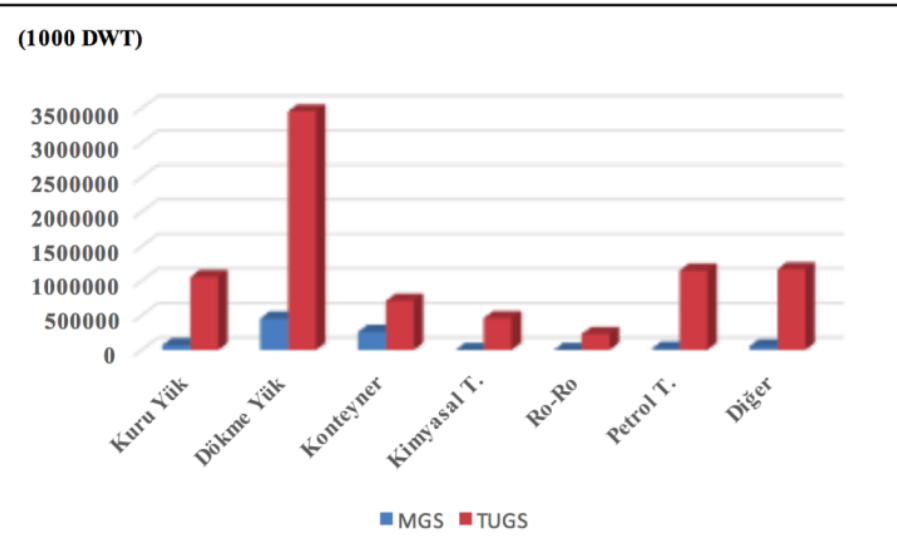

Şekil 1d. Türk Deniz Ticaret Filosunun Siciller Arası Dağıımı (Kaynak: DTO 2016 Deniz Sektörü Raporu)

Sektörün güçlendirilmesine yönelik çalışmalarda kullanılabilecek en etkin yöntemlerden birisi olan kümelenme yaklaşımının sağlıklı bir şekilde uygulanabilmesi için öncelikle Türk deniz taşımacılığı sektörünün mevcut kümelenme seviyesinin özellikle nesnel ve sayısal araçlarla ölçülmesine ihtiyaç bulunmaktadır. Söz konusu ölçümler sonucunda mevcut kümelenmelerin nerelerde ve hangi yoğunlukta konumlandığı anlaşıldıktan sonra; hangi sınıflandırmaya tabi tutulabileceği, yaşam döngüsünün hangi evresinde olduğu, küresel rekabet üstünlük durumu ve avantaj/dezavantajları, ağ ilişkilerinin boyutları, sahip olduğu potansiyel, yenilikçilik kapasitesi, meydana getirdiği katma değer, vb. özellikleri ortaya konabilecektir. Sonrasında elde edilen bulgular, dünyadaki başarılı kümelenme örneklerinin de ışığında, Türk deniz taşımacılığı sektörü için bir kümelenme modeli haline getirilebilecektir.

\section{Yöntem}

Coğrafi Yoğunlaşma Katsayısı (Location Quotient) bölgeler ve şehirler gibi farklı coğrafi konumların sektörel yoğunlaşma ve kümelenme bağlamında ekonomik analizinin ve karşılaştırılmasının yapılmasında kullanılan önemli bir yöntemdir. (Lazzeretti vd. 2009, Rivera 2014, Rivera vd. 2014, Nezerenko ve Kopel 2015, Sartaş 2010, Mutlucan 2015, Othman vd. 2011, Ketels ve Protsiv 2013, Kumar vd. 2016).

Tarihsel perspektif içerisinde kümelenmelerin ve analiz yöntemlerinin incelendiği çalışmada kümelenmelerin dikey-bütünleşik ve yatay bütünleşik olarak ikiye ayrıldığı, Girdi-Çıktı (Input-Output) yönteminin daha çok satıcı-alıcı ilişkisinin bulunduğu dikey- 
bütünleşik yapıya uygun olduğu, birden fazla ortak girdinin (uzmanlaşmış işgücü, fiziki ve bilişim altyapısı ve benzer kaynaklar) bulunduğu yatay-bütünleşik yapıda Coğrafi Yoğunlaşma Katsayısı (Location Quotient) yönteminin kullanılabileceği belirtilmiştir (Vom Hofe ve Chen 2006).

Bu bağlamda deniz taşımacılığı ve destekleyici/alt sektörlerinin Coğrafi Yoğunlaşma Katsayısı (Location Quotient) yöntemiyle, gemi inşa alt sektörünün ise Girdi-Çıktı (Input-Output) yöntemiyle incelenmesinin daha uygun olduğu değerlendirilmektedir. Diğer taraftan Sartaş (2010) Türk gemi inşa sanayinin büyüme dinamiklerini ve geleceğini incelediği çalışmasında söz konusu sektörün Girdi-Çıktı yöntemiyle analizini sağlayacak verilerin bulunmaması sebebiyle kümelenme olup olmadığını anlamak ve kümelenmenin seviyesini ölçmek maksadıyla Coğrafi Yoğunlaşma Katsayısı (LO) yöntemini kullanmış, elde ettiği yüksek LO değerleri ile Tuzla bölgesinde bir gemi inşa kümelenmesi olduğu sonucuna varmıştır. Baltık Denizi'ne kıyısı olan ülkelerin lojistik kümelenmelerinin incelediği çalışmada, kümelenmenin Baltık ülkelerine lojistik ve taşımacılık konularında küresel rekabet sağlayıp sağlayamayacağı sorgulanmış, Coğrafi Yoğunlaşma Katsayısı (LO) yöntemi kullanılarak söz konusu ülkelerin kümelenme seviyeleri karşılaştırılmıştır (Nezerenko ve Kopel 2015).

Türkiye'de denizcilik kümelenmelerine ilişkin çalışmaların eksikliği göz önünde bulundurulduğunda, denizcilik kümelenmesinin merkezinde bulunan ve ana unsuru olan deniz taşımacılığı sektörünün kümelenme seviyesinin özellikle sayısal yöntemler kullanılarak tespit edilmesine ve ulusal ölçekte deniz taşımacılığı kümelenme haritasının çıkartılmasına ihtiyaç bulunmaktadır. Bu bağlamda Türkiye'deki deniz taşımacılığı kümelenmesini sayısal olarak incelemek için Coğrafi Yoğunluk Katsayısı (Location Quotient) kullanılacaktır. Söz konusu yöntem bir bölgedeki belirli bir iş kolundaki istihdam seviyesinin genel istihdam içindeki yerini ortaya koyarak kümelenme seviyesi hakkında çıkarımlar yapılmasına yardımcı olmaktadır. LO için hangi eşik değerinin kullanılması gerektiğine ilişkin tam bir görüş birliği olmamakla beraber belirli bir bölgede kümelenmeden söz edebilmek için LQ'nın 1'den büyük olmasının gerektiği belirtilmektedir (Rivera 2014, Rivera vd. 2014). Literatürde LQ'in istihdam verileri (çalışan sayısı) ile kullanıldığı çalışmaların yansıra işletme sayıları ile de yapılan hesaplamaları bulunmaktadır (Boasson 2001). ABD lojistik sektörünün kümelenme bakış açısıyla incelediği çalışmada ABD'deki lojistik kümelenmelerinin nerelerde olduğu Coğrafi Yoğunluk Katsayısı (Location Quotient (LQ)), Lojistik İşletmelerin Katılımı (Logistics Establishments Participation (LEP)) ve Coğrafi Yoğunluk Gini Katsayısı (Locational Gini Coefficient (LGC)) yöntemleri kullanılarak ortaya konulmuştur (Rivera 2014, Rivera vd. 2014). Bu çalışmada elde edilen LO değerleri, Coğrafi Yoğunluk Gini Katsayısı (Locational Gini Coefficient (LGC)) ve LEP'in bu çalışmaya uyarlanmış şekli olan Deniz Taşımacılığı Şirketleri Katılımı (Maritime Transportation Establishments Participation) (MTEP) değerleri ile desteklenecektir. Bu çalışmada LO değerlerini desteklemek ve/veya sorgulamak amacıyla cirolar, maaşlar-ücretler ve maddi mallara ilişkin brüt yatırımlar gibi verilerin de kullanılabilmesi üzerine denemeler yapılmıştır. 
4.1. Coğrafi Yoğunlaşma Katsayısı (LQ)

$L Q=\frac{e_{i} / e}{E_{i} / E}$

$\mathrm{e}_{\mathrm{i}}$ : i sektöründeki yerel istihdam

e : toplam yerel istihdam

$\mathrm{E}_{\mathrm{i}}$ : i sektöründeki toplam istihdam

E : ülkedeki toplam istihdam

\subsection{Deniz Taşımacılığı Şirketleri Katılımı (MTEP)}

$\mathrm{MTEP}_{\mathrm{j}}=\frac{\mathrm{es}}{\mathrm{ES}}$

$\mathrm{es}_{\mathrm{j}}$ : j bölgesindeki deniz taşımacılığı sektöründeki işletmelerin sayısı ES: ülkedeki deniz taşımacııı̆ı sektöründeki işletmelerin sayısı

MTEP değerinin büyümesi, söz konusu bölgede ve sektörde faaliyet gösteren firmaların sayısının fazla olduğunu göstermektedir. Yüksek sayıda firmanın varlığı ile sağlanan bir yüksek LQ, yoğunlaşmanın ve kümelenmenin ekonomideki dışsallıklardan kaynaklandığını ispatlar. Firma sayısının yeterince yüksek olup olmadığının belirlenmesi için en az \% 0.1'lik (0.001) bir eşik değeri bulunmaktadır (Rivera 2014, Rivera vd. 2014).

\subsection{Coğrafi Yoğunluk Gini Katsayısı (LGC)}

$L G C=\frac{\sum_{i=1}^{n} \sum_{j=1}^{n}\left|x_{i}-x_{j}\right|}{2 n(n-1) \mu}$

$x_{i}$ and $x_{j}$ : Sırasıyla i ve j bölgelerinin LQ değerleri

$\mu$ : referans bölgenin ortalama LQ değeri

$n$ : bölgelerin sayısı

LGC değeri kullanılarak bir sektörün kümelenme seviyesinin diğer sektörlerin kümelenme seviyeleri ile sayısal olarak karşılaştırılabilmesi mümkün olmaktadır. Kümelenme analizi yapılmasında ve kümelenme haritalarının çıkartılmasında kullanılan bir diğer etkili yöntem de Ellison Glaeser Endeksidir (Rivera 2014, Rivera vd. 2014). Söz konusu endeks hesaplanırken, elde edilmesi son derece zor olan “Firmaların Pazar Payları” verileri kullanıldığı için mevcut çalışmaya ithal edilmemiştir.

\section{Veri ve Bulgular}

Deniz taşımacılığı sektörü, AB Ekonomik Faaliyet Sınıflama Sistemine göre NACE 50 olarak sınıflandırılmaktadır. Türkiye İstatistik Kurumu (TÜiK)'nun yayınladığı “Yerel Birim Faaliyetlerine Göre Bazı Temel Göstergeler" verisi kullanılarak Türk Deniz Taşımacılığı Sektörünün (NACE 50) kümelenme analizi yapılmıştır. Söz konusu veriler içinde yer alan yerel birimlere ve faaliyet alanlarına göre oluşturulmuş 2009-2015 yılları arasındaki dönemi kapsayan çalışan sayısı, işletme sayısı, cirolar, maaşlarücretler ve maddi mallara ilişkin brüt yatırımlara ilişkin veriler 7 yıllık ortalamaları 
alınarak kullanılmıştır. İncelenen bölgeler, Türkiye İstatistiki Bölge Birimleri Sınıflandırması (NUTS) gereğince ve denize kıyısı bulunması kriterine göre seçilmiştir.

Tablo 1. Türk deniz taşımacılığı sektörü (NACE 50) çalışan sayılarına göre LQ ve MTEP.

\begin{tabular}{|l|l|l|l|l|}
\hline No & NUTS & il (illerin) Adı & LQ & MTEP \\
\hline $\mathbf{1}$ & TR 10 & İstanbul & 2,22477 & 0,43045 \\
\hline $\mathbf{2}$ & TR 22 & Balıkesir-Çanakkale & 1,50458 & 0,0145 \\
\hline $\mathbf{3}$ & TR 31 & İzmir & 1,02293 & 0,03367 \\
\hline $\mathbf{4}$ & TR 32 & Aydın-Denizli-Muğla & 2,93577 & 0,33177 \\
\hline $\mathbf{5}$ & TR 41 & Bursa-Eskişehir-Bilecik & 0,19266 & 0,00466 \\
\hline $\mathbf{6}$ & TR 61 & Antalya-Isparta-Burdur & 0,95871 & 0,12535 \\
\hline $\mathbf{7}$ & TR 62 & Adana-Mersin & 0,4678 & 0,01398 \\
\hline $\mathbf{8}$ & TR 63 & Hatay-K.Maraş-Osmaniye & 0,21559 & 0,002331 \\
\hline $\mathbf{9}$ & TR 81 & Zonguldak-Karabük-Bartın & 0,16055 & 0,00336 \\
\hline $\mathbf{1 0}$ & TR 90 & Trabzon-Ordu-Giresun-Rize-Artvin-Gümüşhane & 0,11467 & 0,0031 \\
\hline
\end{tabular}

NOT: LQ değeri 0,1'den küçük bölgeler tabloya dahil edilmemiştir.

Kaynak: Yazarların kendi hesaplamalarıdır.

Türk Deniz Taşımacılığı sektörünün çalışan sayıları temel alınarak ve coğrafi yoğunluk katsayıları kullanılarak yapılan kümelenme seviyesi analizinde toplam 4 istatistiki bölgenin (TR 10 İstanbul, TR 22 Balıkesir, Çanakkale, TR 32 Aydın-Denizli-Muğla ve TR 31 İzmir) 1'in üzerinde coğrafi yoğunluk katsayısına sahip olduğu, ayrıca TR 61 Antalya, Isparta, Burdur ve TR 62 Adana, Mersin bölgelerinin coğrafi yoğunluk katsayılarının 1'in altında olmasına rağmen söz konusu eşik değerini yakalama potansiyellerinin yüksek olduğu tespit edilmiştir. Söz konusu Coğrafi Yoğunluk Katsayılarının (LO) yanında Deniz Taşımacılığı İşletmeleri Katılımı (MTEP) değeri de hesaplanmıştır (Tablo 1). TÜiK verilerine göre NACE 50 faaliyet kolunda çalışan sayısı verisi bulunan ve LQ ve MTEP değerleri hesaplanan istatistiki bölgelerden son derece düşük coğrafi yoğunluk katsayılarına sahip oldukları görülenler (LO değeri 0,25'den düşük olanlar) ileriki aşamalardaki analizlere dahil edilmemişlerdir.

Yapılan hesaplamalarda TR 10 İstanbul ve TR 32 Aydın-Denizli-Muğla bölgelerinin LO değerlerinin eşik değeri olan 1'in ve Türkiye ortalaması olan 1,51'in bir hayli üzerinde olduğu, söz konu değerlerin aynı zamanda MTEP değerleri ile de desteklendiği, kümelenme seviyelerinin yüksek olduğu ve bunun büyük ölçüde ekonomideki dışsallıklardan kaynaklandığı tespit edilmiştir. Elde edilen coğrafi yoğunluk katsayıları Türkiye iller haritası üzerine işlenerek Türk deniz taşımacılığı sektörünün kümelenme haritası çıkartılmıştır (Şekil 2). Denize kıyısı olmayan iller haritaya işlenmemiştir. 


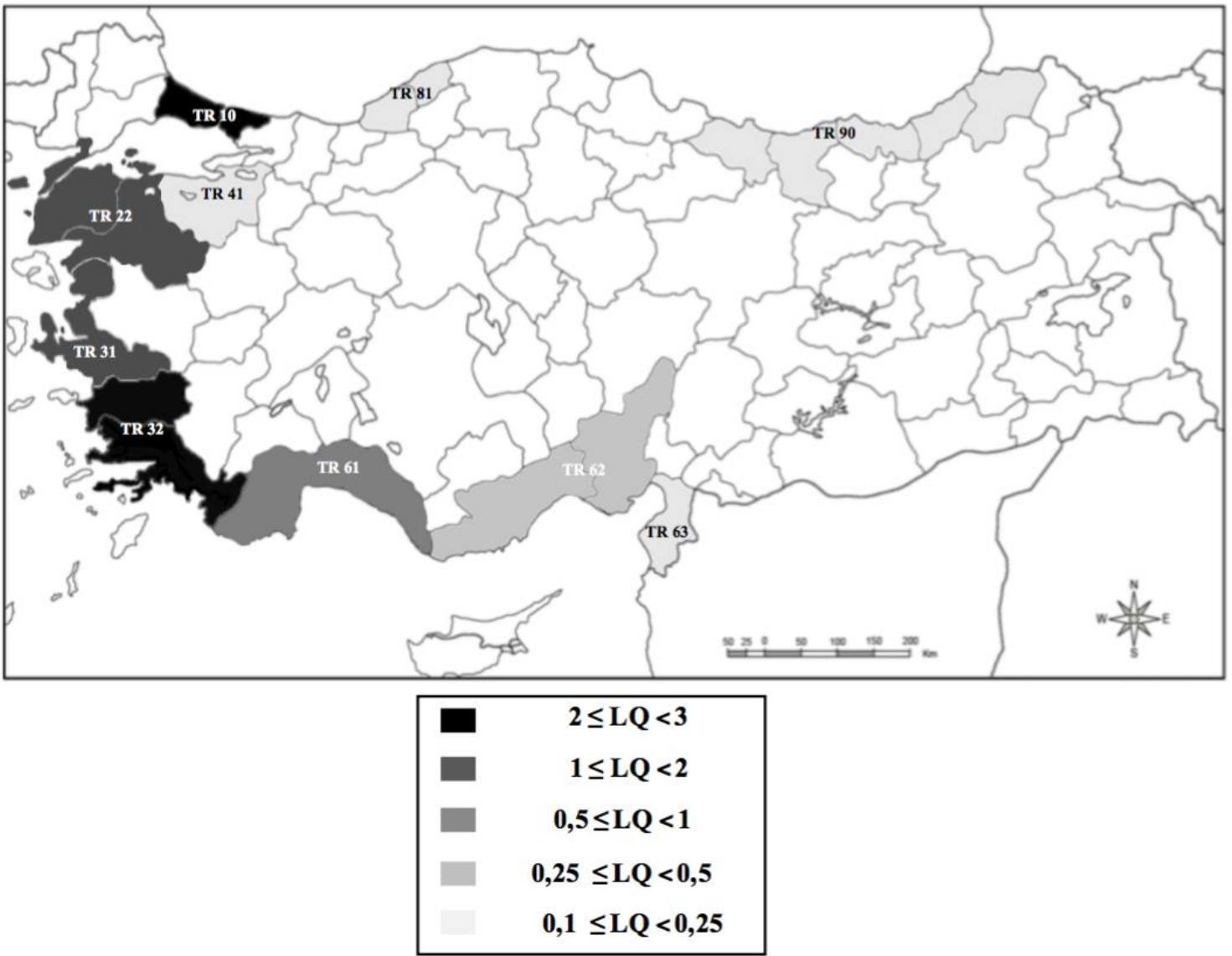

Şekil 2. Türk deniz taşımacılığı sektörü (NACE 50) çalışan sayılarına göre hesaplanmış coğrafi yoğunluk katsayıları haritası.

Coğrafi Yoğunluk Katsayısı değerlerinin grafiksel gösterimi Şekil 3'de yer almaktadır. Çalışan sayıları kullanılarak hesaplanmış LO değerlerine göre TR 10 İstanbul ve TR 32 Aydın-Denizli-Muğla bölgeleri öncelikli olmak üzere TR 22 Balıkesir, Çanakkale ve TR 31 İzmir bölgelerinin de kümelenme özelliğine sahip olduğu görülmektedir. İncelemeye değer bir husus olarak TR 61 Antalya, Burdur bölgesinin 1'in hemen altında kalan LO değerine $(0,95871)$ rağmen kritik eşik değerin üzerinde bir MTEP değerine $(0,12535)$ sahip olmasıdır. Bu anlamda kümelenme potansiyeli bulunduğu söylenebilir. Benzer şekilde TR 62 Adana, Mersin bölgesinin de oldukça düşük LO $(0,4678)$ ve $\operatorname{METP}(0,01398)$ değerlerine rağmen sahip olduğu nispeten yüksek ciro değeri

( $L O$ ciro $=1,05351$ ) ile gelecekte deniz taşımacıllı̆ı kümelenmesine dönüşebileceği değerlendirilmektedir. Fakat LQ büyüme oranının eksi olması bu bölgenin gelişmiş bir deniz taşımacılığı kümelenmesi olma umutlarını desteklememektedir. 


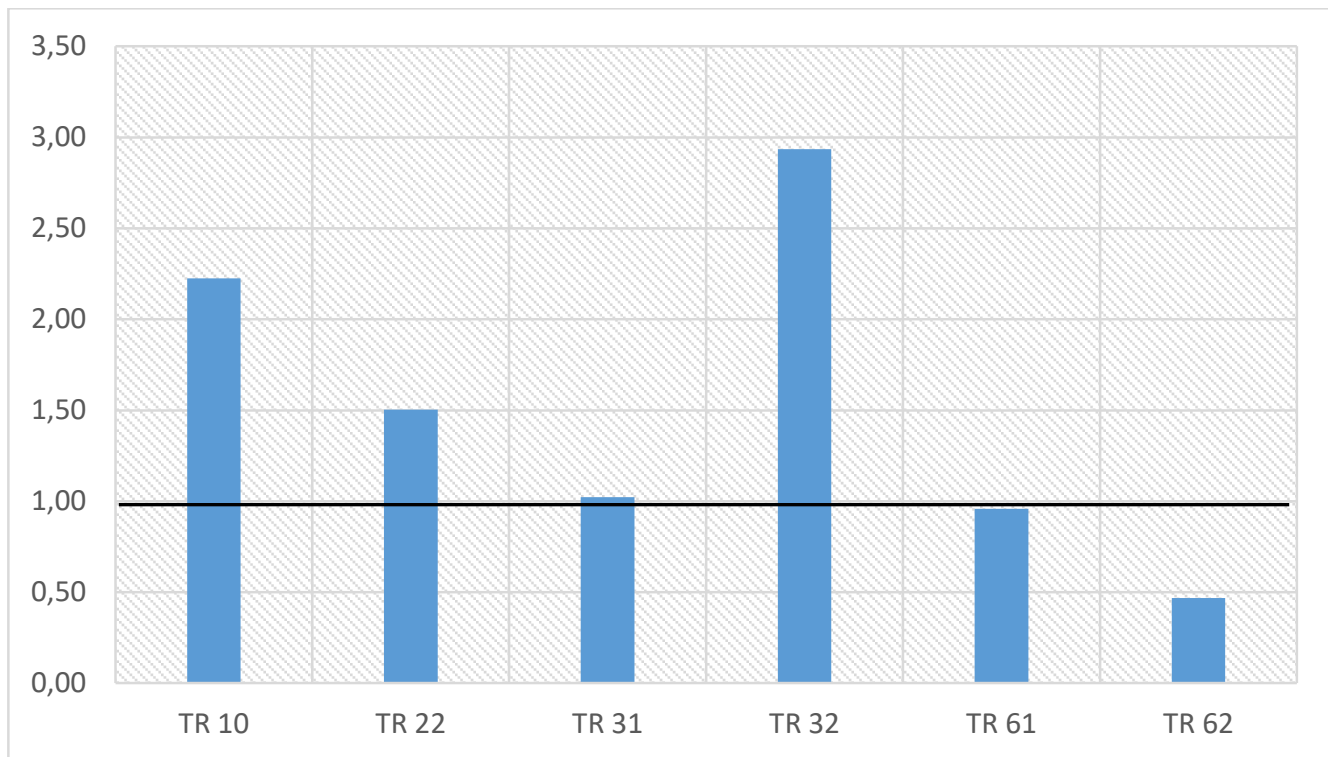

Şekil 3. Türk deniz taşımacılığı sektörü (NACE 50) çalışan sayılarına göre hesaplanmış coğrafi yoğunluk katsayılarının grafik gösterimi.

Ilk aşamada yapılan LO ve MTEP hesaplamalarının ardından sayısal olarak kümelenme analizinin yapılmasının anlamlı olacağı değerlendirilen toplam 6 bölgeye ait veriler kullanılarak LO değerleri, bu çalışmada ciro, maaşlar-ücretler ve maddi mallara ilişkin brüt yatırımlar değerleriyle de hesaplanarak analizlere dahil edilmiştir. Literatürde genelde çalışan sayılarıyla, nadiren de işyeri sayılarıyla hesaplanan LO değerlerinin söz konusu yeni değişkenler kullanılarak hesaplanmasının kümelenme potansiyellerinin daha iyi analiz edilmesini sağladığı değerlendirilmektedir. Kolay karşılaştırılabilmesi bakımından gerek istatistiki bölgeler gerekse de değişkenler temelinde Şekil 4'de grafiksel olarak gösterilmiştir.

Şekil-4 incelendiğinde; çalışan ve işyeri sayılarına göre kümelenme özellikleri gösteren TR 32 Aydın-Denizli-Muğla bölgelesinin konu cirolar olduğunda ( $($ O ciro = 0,55852) son derece zayıf konumda bulunduğu görülmektedir. Söz konusu durumun bu bölgelerdeki deniz taşımacılığı faaliyetlerinin küçük teknelerle yapılan turistik yolcu taşımacılığı şeklinde gerçekleştirilmesinden kaynaklandığı değerlendilmektedir. Mevcut kümelenme yapısının cirolar anlamında da güçlendirilebilmesi için verimliliği ve katma değeri yüksek sonuçlar verecek uygulamalara geçilmesinin gereği açıktır. Aksi halde sürdürülebilir olmaktan çıkan kümelenmelerin yaşam döngüsünün bir parçası olarak durağanlaşması ve gerilemesi kaçınılmaz olacaktır. Ayrıca yapılacak çalışmaların bölgedeki turizm kümelenmesi ile eşgüdümlü olmasının gerekliliği de çok açıktır. TR 10 i̇stanbul, 2,73844'lük LO yatırım değeriyle eşik değerinin üzerinde yeterli performans gösteren tek bölgedir. Ardından 0,65085'lik LO yatırım değeriyle TR 31 İzmir bölgesi gelmektedir. 


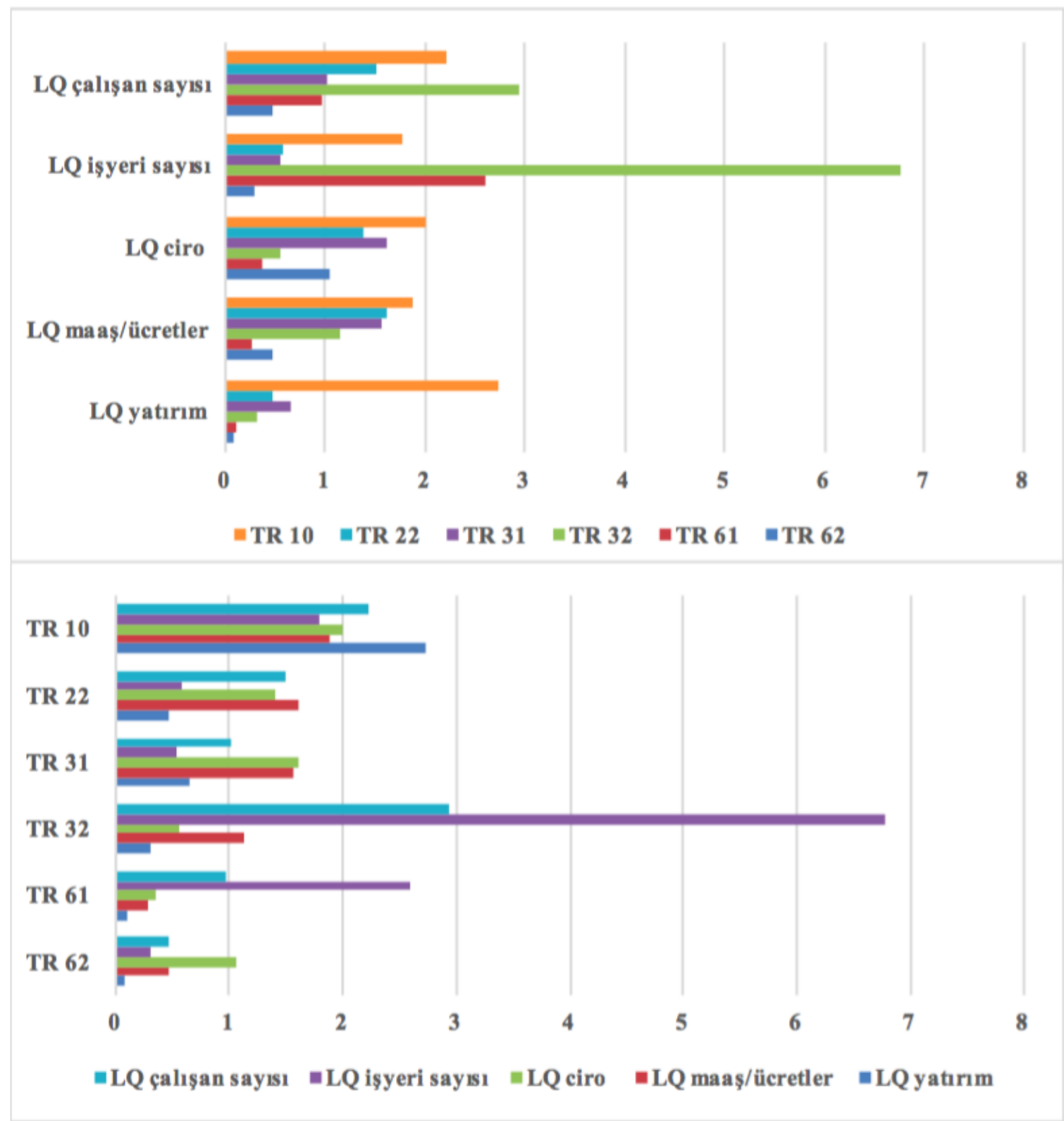

Şekil 4. Türk deniz taşımacılığı sektörünün (NACE 50) çalışan sayıları, işyeri sayıları, cirolar, maaş-ücretler ve maddi mallara ilişkin brüt yatırımlara göre hesaplanmış coğrafi yoğunluk katsayılarının grafik gösterimi

Şekil 5'de Deniz Taşımacılığı Şirketlerinin Katılımı (MTEP) değerleri grafiksel olarak gösterilmiştir. TR 10 İstanbul (METP = 0,43045), TR 32 Aydın-Denizli-Muğla (MTEP = 0,33177) ve TR 61 Antalya, Burdur (MTEP = 0,12535) bölgelerinin eşik değer olan \% 0,1 'in üzerinde olduğu görülmektedir. MTEP değerinin eşik değerden yüksek olması söz konusu bölgelerde ekonomideki dışsalıkların etkili olduğu, bir başka ifadeyle az sayıda büyük ölçekli ve içine kapalı şirket yerine çok sayıda birbirleriyle etkileşimde olan şirketin bulunduğu (söz konusu şirketlerin birbirleri arasındaki etkileşim ve iletişimin seviyesinin ayrıca analiz edilmesine ihtiyaç bulunmaktadır. Çok sayıda şirketin varlığı sağlıklı bir kümelenme anlamına gelen yüksek etkileşimi garanti etmemekle birlikte potansiyeli oldukça arttırmaktadır) anlamına gelmektedir. 


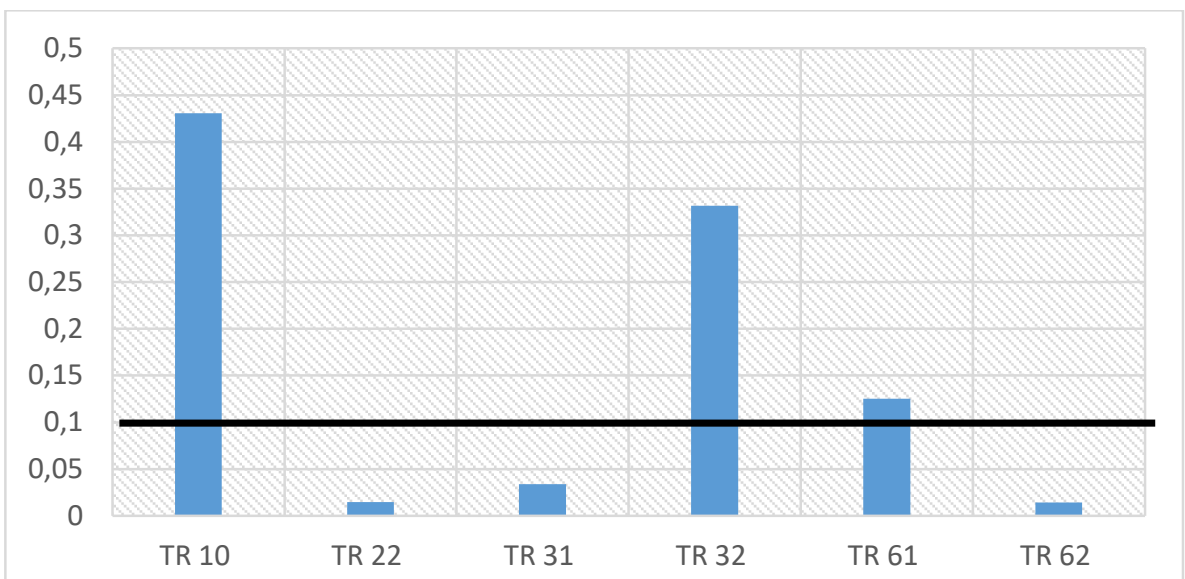

Şekil 5. Türk deniz taşımacılığı sektörü (NACE 50) işyerlerinin katılımı oranı (MTEP).

Şekil 6'da çalışan sayılarına göre hesaplanmış coğrafi yoğunluk katsayılarının ve 20092015 yılları arasındaki değişim oranının serpilme diyagramı gösterimine yer verilmiştir.

TR 32 Aydın-Denizli-Muğla bölgesinin hem LO değerinin $(2,93577)$ hem de LO artış oranının (\% 114) Türkiye ortalamasının oldukça üzerinde olduğu, TR 10 ístanbul bölgesinin yüksek bir LO değerine $(2,22477)$ sahipken söz konusu değerin son 7 yılda \% 14 oranında azaldığı görülmektedir. TR 22 Balıkesir, Çanakkale (\% 27), TR 31 İzmir

(\% 11) ve TR 61 Antalya, Burdur (\% 9) bölgelerinin Türkiye ortalaması (\% 20) civarında LO artışına sahip olduğu tespit edilmiştir. TR 62 Adana, Mersin bölgesinin LO azalışı $\%$ 27'yi bulmuştur. Gerek LO değerinin gerekse de LO büyüme oranının Türkiye ortalamasının çok altında olması söz konusu bölgenin kümelenme potansiyeli hakkında ciddi endişe uyandırmaktadır.

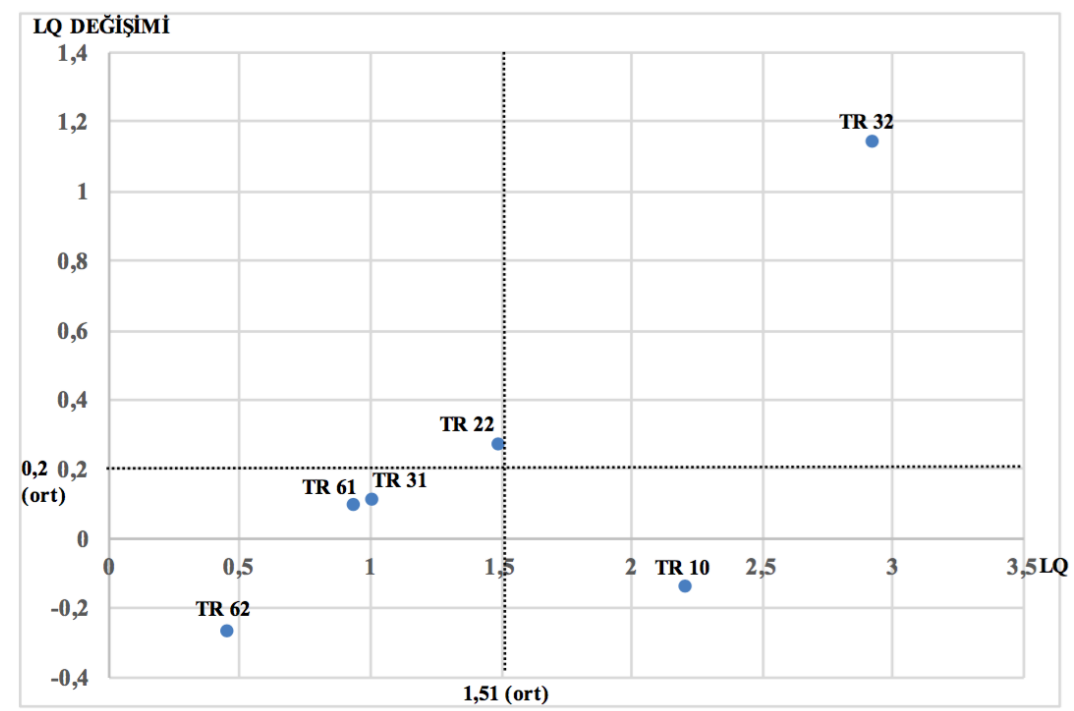

Şekil 6. Türk deniz taşımacılığı sektörü (NACE 50) çalışan sayılarına göre hesaplanmış coğrafi yoğunluk katsayılarının ve 2009-2015 yılları arasındaki değişim oranlarının serpilme diyagramı gösterimi.

Son olarak söz konusu 6 istatistiki bölge temel alınarak Türk deniz taşımacılığı kümelenmesinin Coğrafi Gini Katsayısı $(\mathrm{LGC})=0,36468$ olarak hesaplanmıştır. Söz konusu değerin kapsama alanı 6 istatistiki bölge olacak şekilde deniz taşımacılığı sektörünün diğer sektörler ile karşılaştırılmasında kullanılabileceği değerlendirilmektedir. 


\section{Sonuç}

Küresel rekabet gücünün elde edilmesinde ve sürdürülmesinde son derece etkili bir uygulama olarak karşımıza çıkan kümelenmenin özellikle sayısal yöntemler kullanılarak analiz edilmesine ihtiyaç bulunmaktadır. Bu kapsamda; Coğrafi Yoğunluk Katsayısı (Location Quotient (LQ)), Deniz Taşımacılığı Şirketleri Katılımı (Maritime Transportation Establishments Participation) (MTEP)) ve Coğrafi Yoğunluk Gini Katsayısı (Locational Gini Coefficient) (LGC)) kullanılarak Türk deniz taşımacılığı sektörünün kümelenme seviyesi ölçülmüştür.

Yapılan ölçümler sonucunda TR 10 İstanbul bölgesinin deniz taşımacılığında tüm değişkenler göz önünde bulundurulduğunda sayısal olarak tam bir kümelenme özelliği taşıdığı tespit edilmiştir. Son yıllarda LO değerinde yaşanan düşüşe rağmen İstanbul deniz taşımacılığı kümelenmesinin dünyadaki benzer kümelenmelerle rahatlıkla karşılaştırılabilecek düzeyde olduğu değerlendirilmektedir. Ayrıca TR 32 Aydın-DenizliMuğla bölgesindeki deniz taşımacılığı sektörünün kümelenme seviyesinin ciro, maaşlar/ücretler ve yatırım değişkenleri dikkate alınmaz ise çok yüksek olduğu görülmektedir. Söz konusu durumun bölgede deniz taşımacılığının daha çok yolcu tekneleriyle turizm amaçlı yapılan yolcu taşımacılığı şeklinde yaygınlaşmasından kaynaklandığı değerlendirilmektedir. TR 31 İzmir bölgesindeki deniz taşımacılığı sektörü kritik eşik değeri küçük bir farkla aşsa da güçlü bir kümelenme potansiyeline sahip olduğu anlaşılmaktadır. Söz konusu bölgenin sahip olduğu kruvaziyer liman olma özelliği ve Çandarlı limanının gelişimi kapsamında gelecekte güçlü bir deniz taşımacılığı kümelenmesi haline gelebileceği değerlendirilmektedir.

Son olarak TR 22 Balıkesir, Çanakkale bölgesinin kümelenme özelliği gösterdiği, TR 61 Antalya, Burdur ve TR 62 Adana, Mersin bölgelerinin ise henüz gereken kritik eşikleri aşamamış olmalarına rağmen özellikle TR 61 Antalya, Burdur bölgesinin kümelenme potansiyelinin yüksek olduğu görülmüştür.

Elde edilen bulgular şimdiye kadar Türk deniz taşımacılığı kümelenmesi üzerine yapılmış ilk ve tek çalışma olan Deval ve Saman (2005)'ın ortaya koydukları ile de örtüşmektedir. Deval ve Saman (2005) deniz taşımacılığı firmalarının İstanbul'da yoğunlaşması, pazarlara, müşterilere ve iş ortaklarına yakınlık, gemi inşa sanayinin büyük ölçüde İstanbul'da konuşlanmış olması, güçlü ulaşım ve iletişim altyapısının varlığı, yaşam kalitesinin yüksekliği gibi avantajların İstanbul'u bir deniz taşımacılığı kümelenmesi haline getirdiğini belirtmiş̧tir.

Bu çalışmada istihdam verileri kullanılarak elde edilmiş LO değerlerini desteklemek ve/veya sorgulamak amacıyla iş yeri sayıları, cirolar, maaşlar-ücretler ve maddi mallara ilişkin brüt yatırımlar gibi verilerin de kullanılabilmesi üzerine denemeler yapılmıştır. Bu kapsamda genelde çalışan zaman zaman da işyeri sayısı kullanılarak yapılan LO hesaplamalarının işletmelerin daha çok küçük ve orta ölçekli olduğu bölgelerde yanıltıcı sonuçlar verebileceği ve kümelenme seviyesinin olduğundan yüksek çıkabileceği görülmüştür. Bunun gibi durumlarda ciro, maaşlar/ücretler ve maddi mallara ilişkin brüt yatırımlar gibi ekonomik performansı ve katma değer oluşumunu daha iyi yansıtan değişkenlerin analizlere dahil edilmesinin çalışan ve işyeri sayısının kullanıımasına nazaran daha sağlıklı sonuçlar alınmasına yardımcı olacağı değerlendirilmektedir. 
Gelecekte yapılacak çalışma olarak, deniz taşımacııı̆ı firmaları arasındaki ağ ilişkilerini ele alan ve bu çalışmada hesaplanan LO değerlerinin doğru olup olmadığının kontrol edilmesini sağlayan bir anket çalışmasının yapılması gerekmektedir. Ayrıca elde edilecek uygun veriyle diğer alt sektörler olan limanlar ve gemi inşa sanayi için LO yöntemi kullanılabilecektir.

Türk deniz taşımacılığı kümelenmelerinin yerel ihtiyaçlar göz önünde bulundurularak fakat ulusal seviyede bütünleşik bir bakış açısıyla güçlendirilmelerinin Türkiye'nin küresel rekabet gücüne ulaşmasında son derece önemli olduğu değerlendirilmektedir.

\section{KAYNAKÇA}

Akıncılar Tan, T. (2011). Askeri ve sivil teknolojinin birleşimi amaçlı küme modeli - Askeri gemi yapımı örneği. Doktora Tezi, Kara Harp Okulu, Ankara.

Alüftekin, N., Yüksel, Ö., Taş, A., Çakar, G. ve Bayraktar, F. (2009). Küresel krizden çıkışta kümelenme modeli: Tekstil ve hazır giyim sektörü örneği. ZKÜ Sosyal Bilimler Dergisi, 5 (10), 1-19.

Aziz, K.A. ve Norhashim, M. (2008). Cluster-based policy making: Assessing performance and sustaining competitiveness. Review of Policy Research, 25 (4), 349-375. doi: 10.1111/j.15411338.2008.00336.x.

Brett, $\mathrm{V}$. (2007). The potential for clustering of the maritime transport sector in the Greater Dublin Region. PhD diss., National College of Ireland, Dublin.

Bulu, M., Eraslan, í. H. ve Kaya, H. (2006). Türk elektronik sektörünün rekabetçilik analizi. İstanbul Ticaret Üniversitesi Sosyal Bilimler Dergisi, 5(9), 49-66.

Deniz Ticaret Odası. (2017). 2016 Deniz Sektörü Raporu, İstanbul.

De Langen, P.W. (2002). Clustering and performance: the case of maritime clustering in the Netherlands. Maritime Policy and Management, 29 (3), 209-221. doi:10.1080/0308883021013260 5.

Delgado, M., Porter, M. E. ve Stern, S. (2010). Clusters and entrepreneurship. Journal of Economic Geography, 10 (4), 495-518. doi:10.1093/jeg/lbq010.

Delgado, M., Porter, M. E. ve Stern, S. (2014). Clusters, convergence, and economic performance. Research Policy, 43, 1785-1799. doi:10.1016/j.respol.2014.05.007.

Deval, O. ve Saman, M. (2005). Maritime cluster of Istanbul. MSc diss., City College, London.

Enright, M.J. (2003). Regional clusters: What we know and what we should know, In Innovation Clusters and Interregional Competition, edited by J. Bröcker et al., 99-129. Berlin: SpringerVerlag.

Gebeş, F. ve Battal, Ü. (2014). Türkiye'de havacılık kümelenmeleri ve finansman sorunları. Niğde Üniversitesi iiBF Dergisi, 7 (1), 273-288.

Gürbüz, C. (2008). An integrated approach to the interconnected maritime services of Turkey. MSc diss., World Maritime University, Malmo.

Karahan, A. (2014). Kamu işletmelerinin rekabet gücü analizi ve ulaştırma sektörū örneği. Maliye Finans Yazıları, 28 (102), 25-44.

Ketels, C.H.M. ve Memedovic, O. (2008). From clusters to cluster-based economic development. Int. J. Technological Learning, Innovation and Development, 1(3), 375-392. doi:10.1504/IJTLID.2008.019979.

Ketels, C. ve Protsiv, S. (2013). Clusters and the new growth path for Europe - Research paper on the role of clusters for the new growth path. Working Paper no14.fileadmin/documents/pdf/Workingpapers/WWWforEurope_WPS_no014_MS47.pdf.

Kocaoğlu, i.U. (2013). Firma rekabet gücünü artıran faktörler ve kümelenme yaklaşımı: Türkiye doğal tas, kümelenmelerinin rekabet gücü açısından incelenmesi. Doktora Tezi, Ege Üniversitesi, İzmir.

Krugman, P. (1991). Increasing returns and economic geography. The Journal of Political Economy, 99(3), 483-499. doi:10.1086/261763. 
Kumar, I., Zhalnin, A., Kim, A. ve Beaulieu, L. J. (2016). Transportation and logistics cluster competitive advantages in the U.S. regions: A cross- sectional and spatio-temporal analysis. Research in Transportation Economics, (2016), 1-12. doi:10.1016/j.retrec.2016.07.028.

Lazzeretti, L., Boix, R. ve Capone, F. (2009). Why do creative industries cluster? An analysis of the determinants of clustering of creative industries. IERMB Working Paper in Economics, 9 (2).

Lundequist, P. ve Power, D. (2002). Putting Porter into practice? Practices of regional cluster building: Evidence from Sweden. European Planning Studies, 10 (6), 685-704. doi:10.1080/0965431022000003762.

Mutlucan, N. C. (2015). Competitive Advantage and clusters:isepidence from textile, wearing apparel, carpet, automotive, tourism and furniture clusters in Turkey. PhD diss., Boğaziçi University, Istanbul.

Nezerenko, O. ve Koppel, O. (2015). Formal and informal macro-regional transport clusters as a primary step in the design and implementation of cluster-based strategies. Transport and Telecommunication, 16 (3), 207-216. doi:10.1515/ttj-2015-0019.

Othman, M. R., Bruce, J. G. ve Abdul Hamid, S. (2011). The strength of Malaysian maritime cluster: The development of maritime policy. Ocean \& Coastal Management, 54, 557 - 568. doi:10.1016/j.ocecoaman.2011.02.0 04 .

Öz, Ö. (2004). Clusters and Competitive Advantage. Dordrecht: Springer.

Porter, M.E. (1990). The Competitive Advantage of Nations. New York, NY: Free Press, MacMillan.

Porter, M.E. (1998). The Adam Smith address: Location, clusters, and the new microeconomics of competition. Business Economics, 98 (1), 7-13.

Porter, M.E. (2000). Location, competition, and economic development: Local clusters in a global economy. Economic Development Quarterly, 14 (1), 15-35. doi:10.1177/089124240001400105.

Reve, T. ve Sasson, A. (2015). Theoretical and methodological advances in cluster research. Competitiveness Review, 25 (5), 524-539. doi:10.1108/CR-06-2015-0062.

Rivera, L. (2014). Logistics clusters: Prevalence and impact. PhD diss., Massachusetts Institute of Technology, Boston.

Rivera, L., Sheffi, Y. ve Welsch, R. (2014). Logistics agglomeration in the US. Transportation Research Part A, 59, 222-238. doi: 10.1016/j.tra.2013.11.009.

Rocha, H. O. ve Sternberg, R. (2005). Entrepreneurship: The role of clusters theoretical perspectives and empirical evidence from Germany. Small Business Economics, 24, 267-292. doi:10.1007/s11187-005-1993-9.

Rosenfeld, S. A. (2003). Expanding opportunities: Cluster strategies that reach more people and more places. European Planning Studies, 11 (4), 359-377. doi: 10.1080/09654310303643.

Sartaş, M. (2010). Analysis of the growth dynamics in Turkish commercial shipbuilding sector and its prospects. MSc diss., Middle East Technical University, Ankara.

Saxenian, A.L. (1996). Inside-Out: Regional networks and industrial adaptation in

Silicon Valley and Route 128. Cityscape: A Journal of Policy

Development and Research, 2 (2), 41-60.

Van den Berg, H. ve Lewer, J. J. (2007). International Trade and Economic

Growth. New York, NY: M.E. Sharpe, Inc.

Viederyte, R. (2014a). Lithuanian maritime sector's economic impact to the whole Lithuanian economy. Procedia - Social and Behavioral Sciences, 143, 892-896. doi:10.1016/j.sbspro.2014.07.512.

Viederyte, R. (2014b). Lithuanian maritime sector's clustering economic impact evaluation. Procedia - Social and Behavioral Sciences, 156, 292-297. doi:10.1016/j.sbspro.2014.11.191.

Vom Hofe, R. ve Chen, K. (2006). Whither or not industrial cluster: conclusions or confusions?. The Industrial Geographer, 4 (1), 2-28. geographer.lib.indstate.edu/ vom\%20Hofe.pdf.

Wolfe, D. A. ve Gertler, M. S. (2004). Clusters from the inside and out: Local dynamics and global linkages. Urban Studies, 41 (5/6), 1071-1093. doi:10.1080/00420980410001675832

Wijnost, N. (2006). Dynamic European Maritime Clusters. Amsterdam, NL: IOS Press BV. 